\title{
Trees on Farmland: Sheanut Distribution and Production in the Niger State, Nigeria
}

\author{
Misa MASUDA Institute of Agriculture and Forestry, University of Tsukuba, Tsukuba 305, Japan \\ Suleiman KUDU Government Girls Secondary School, Mokwa, Niger, Nigeria
}

\begin{abstract}
Butyrospermum paradoxum is a common species in upland habitats of Savanna zone in West Africa. Local people have traditionally utilized fat extracted from the kernels for cooking, and it was one of staple trading commodities in the northern Nigeria as well. Recent reports including those on forestry have made, however, almost no mention of it, as it lost the position in commercial trade. This was mainly brought by declining demand, especially in domestic market. Through a case study in the Niger state, it is ascertained that the trees are selectively left on farmland at the time of clearing. Harvesting activities are done only by women, which provide an important opportunity for them to earn income at their own disposal. In consequence, it seems this interaction between man and sheanut has produced significant effect on the distribution range and density of the trees. To find a countermeasure to forest deterioration which has become a nation-wide problem in Nigeria, it is required to encourage such customary activities by local people through stabilization of the market of non-wood forest products and introduction of more effective and proper land management system including tree crops.
\end{abstract}

Key Words: sheanut / Butyrospermum paradoxum / non-wood forest products / Nupe / Niger state / Nigeria

To do field research on sheanut, or shea butter tree (Butyrospermum paradoxum HEPPER.) may be not as exciting as other unknown forest products. It is a quite common tree species not only in Nigeria but among neighboring countries located in Guinea and southern Sudan savanna zones. The seed contains around $46 \%$ of fat by weight (Norchem Industries, Bida, interview) and is pointed out as one of the three oil seeds produced from tropical forests: the others are mahua or mowra butter tree (Madhuca spp.) in India and illipe nut tree (Shorea spp.) in Borneo (Imperial Institute, 1920).

The specimens of sheanut tree were first brought to England by Mungo Park who traveled West Africa at the end of the 18th century, and identified by Ferdinand Bassi, curator of the Botanical Garden of Bologna. The chemical structure of fat contained in kernels attracted European industries such as soap manufacturing as a substitute of mutton fat (Allen and Thomson, 1968). In 1878, shea butter accounted for $22.2 \%$ (1,500 tons) by quantity or 18.8 $\%(£ 58,000)$ by value of the total produce estimated to be shipped from the Niger valley (Dike, 1956). Sheanut became a major export commodity in the northern region, which made the High Commissioner state "the staple of Northern Nigeria" at the beginning of the 20th century. The annual export quantity of sheanut fluctuated between 10,000 and 3,000 tons from the 1900s to 1930s, once declined during World War II, but recovered to reach around 
Table 1. Export of forest products $(£ 1,000)$.

\begin{tabular}{|c|c|c|c|c|c|c|c|c|}
\hline \multirow{2}{*}{ Product } & \multicolumn{2}{|c|}{1935} & \multicolumn{2}{|c|}{1937} & \multicolumn{2}{|c|}{1940} & \multicolumn{2}{|c|}{1950} \\
\hline & Value & $\%$ & Value & $\%$ & Value & $\%$ & Value & $\%$ \\
\hline Timber & 156.0 & 73.0 & 201.0 & 48.4 & 218.0 & 50.5 & $1,059.0$ & 67.6 \\
\hline Wild Rubber & 0.5 & 0.2 & 1.4 & 0.3 & 2.1 & 0.5 & 1.0 & 0.1 \\
\hline Gum Arabic & 10.6 & 5.0 & 9.9 & 2.4 & 30.8 & 7.1 & 62.1 & 4.0 \\
\hline Sheanut & 10.7 & 5.0 & 83.4 & 20.1 & 60.8 & 14.1 & 53.4 & 3.4 \\
\hline Piassava* & 5.8 & 2.7 & 9.8 & 2.4 & 11.8 & 2.7 & 146.5 & 9.4 \\
\hline Others & 30.0 & 14.0 & 110.0 & 26.5 & 108.0 & 25.0 & 244.0 & 15.6 \\
\hline Total & 213.6 & 100.0 & 415.5 & 100.0 & 431.5 & 100.0 & $1,566.0$ & 100.0 \\
\hline
\end{tabular}

15,000 tons per annum in the 1950 s, which were mainly derived from eastern Niger province and Zaria province. These were collected at Bida and Zaria and transported through railroads (Buchanan and Pugh, 1955; Momodu, 1987). Table 1 shows the share of sheanut in forest products export, from which the status of sheanut can be compared to that of gum arabic.

As for domestic consumption, Mungo Park has ever described the delicious flavor of the butter, which seems too exaggerated in truth, and made an emphasize on the importance at domestic consumption (Roche, 1989). According to the account of the Niger River expedition in the middle 19th century, shea butter was one of common trading commodities at local fairs held along the river, and there is a description on guinea corn pounded with shea butter (Allen and Thomson, 1968).

In contrast to public interest during the colonial period, literature on current conditions of sheanut shows depressing outlooks. The trees are left in wild state, endangered by inadequate treatment by local people, and neglected by the government (Momodu, 1987; Roche, 1989). Thus the objectives of this study is first to elucidate distribution of sheanut trees and the production system to see the potential of the resources for local people.

\section{DATA COLLECTION}

Sheanut trees on the roadside could be easily observed from a car. Along the roads from Ibadan to the northern border with the Republic of Niger by way of Jebba, Mokwa, Birnin Gwari, Kaduna, Kano, and Katsina, the trees started to appear in the area around $50 \mathrm{~km}$ to the north of Ibadan, and became more abundant in the vicinity of Jebba, where sheanut together with locust bean (Parkia filicoidea WELW. ex OLIV.) were regularly distributed over upland fields. Such a scene was observed as far as Kaduna, after which these two remarkable tree species on farmland were replaced by other species, for example, Acacia albida DELILE and baobab (Adansonia digitata $\mathrm{L}$.). Zoning by vegetation types and location of the main state capitals are shown at Figure 1. Since Bida, the second largest city of the Niger state and the seat of the emirate controlling the Nupe people as well, was once the flourishing center of sheanut collection and distribution, a sample village, Gadza village, was selected in the fringe of 


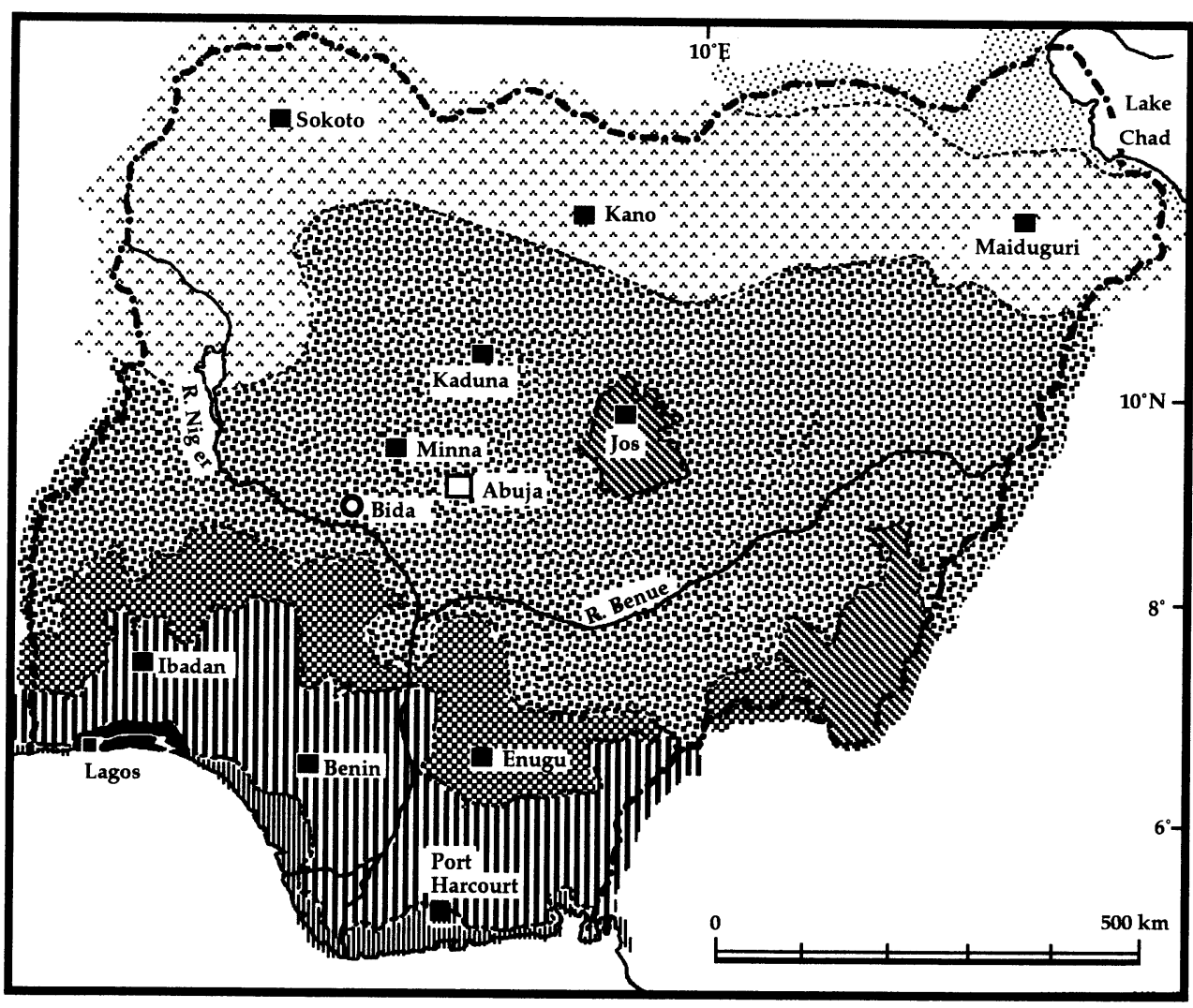

Fug. 1. Main cities and vegetation types of Nigeria

- Federal Capital
- State Capital
- Local Town

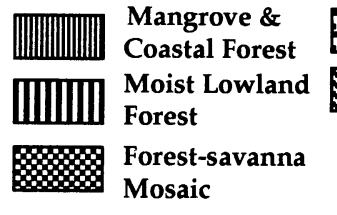

Bida. The location of the settlement and estimated border of the village are given at Figure 2. The average annual rainfall of this area is approximately 1,200 mm (Niger State Committee on Desertification Problems, 1988).

Land use patterns at the village are classified into four categories: a housing site, a tree garden adjoining to the housing site, rain fed paddy fields in lowland, and upland fields with bush fallow system. Along the path running through the village from the north to the south, the patterns markedly change in the order of upland, the housing site, tree garden, and lowland. Accordingly, two sample plots with $100 \mathrm{~m} \times 100 \mathrm{~m}$ to measure trees and annual crops distribution were set up:
Source: K. M. Barbour et al., Nigeria in Maps Guinea Savanna Sudan Savanna

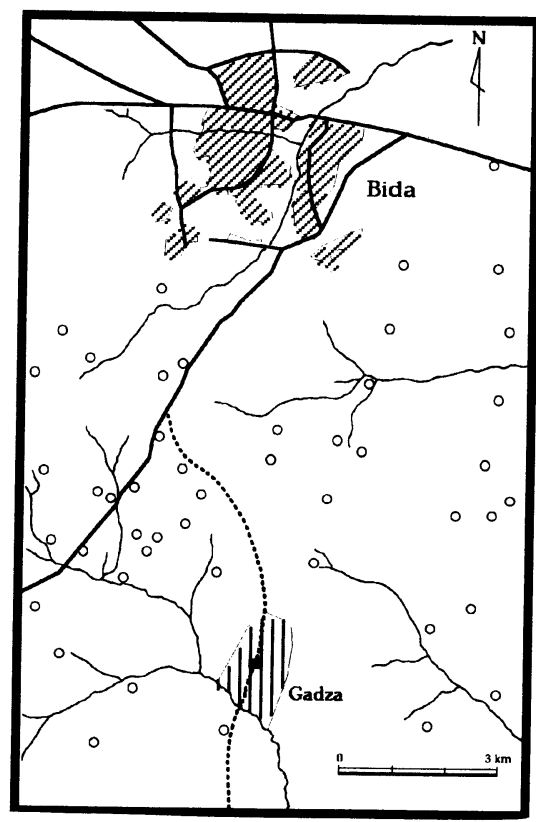

Fig. 2. Location of GadzaVillege Source: Topography maps (1970) with GPS measurement 
one in the middle part of tree garden and the other in upland $600 \mathrm{~m}$ distant from the settlement to the north.

The form of Gadza village settlement can be classified into nucleated type. All of the houses are gathered and attached each other, forming a dense labyrinthine mixture of small houses, grain storage barns, sheds of goat and pigeon, open yards for post-harvest processing of agricultural crops, and walls made of soil. The settlement can be divided into nine compounds (emi), among which the largest compound was selected as a sample to make an overall interview on social structure and production system including sheanut.

\section{RESULTS}

\section{Social structure}

Gadza village is ruled by a village chief (etsu lati) and a farmers chief (etsu enunuchizhi). Etsu lati is selected among the oldest men and holds the position for life. Etsu enunuchizhi can not be selected from the same emi with that of etsu lati, and he controls the matters related to agricultural activities, for example, to determine the time for cropping, to preserve seeds, to supervise farmers, and to maintain irrigation canals. Emi in the Nupe language means a house and also corresponds to both a compound and an extended family that comprises the compound. Each emi is ruled by emi tsuo (owner of the compound), which position is held by the oldest man of the emi.

Although members of an emi are bound together by stronger ties than that with other emis and collaborate one another in every aspects of daily life, each household that consists of a man and his wives, their unmarried children, and sometimes married sons and wives with grandchildren, when they have not yet established economic bases, is economically independent. In case of the sample emi, Emi A, it consists of four households, that is, the widow of the late emi tsuo with her adopted granddaughter, and the families of her three sons. Since the eldest son was in the army when his father died, the second son, which means he was the oldest at that time, has been serving as the emi tsuo and also etsu enunuchizhi even after the eldest son retired and returned to the village. The Nupe people hold virilocality system, so there are no daughters of the late emi tsuo living at the same compound.

The total members comprising Emi A are 34 people. Based on the population of Emi A which is the largest compound, the total population of Gadza village can be estimated to be around 200 .

\section{Land tenure}

In the Niger state, neither analysis of legislation nor observation at village level is sufficient to clarify the whole of land tenure system. It is necessary to step into the structure of the emirate, because traditional social relations between village people and the emirate still exist. Gadza village annually supplies a part of harvests to the emirate through tsoda and natsu, both of which seems to be a sort of titles of the emirate retainers. Though it is not accepted as compulsory but as voluntary tributes by the village people, they still recognize tsoda and natsu to be their landlord. 


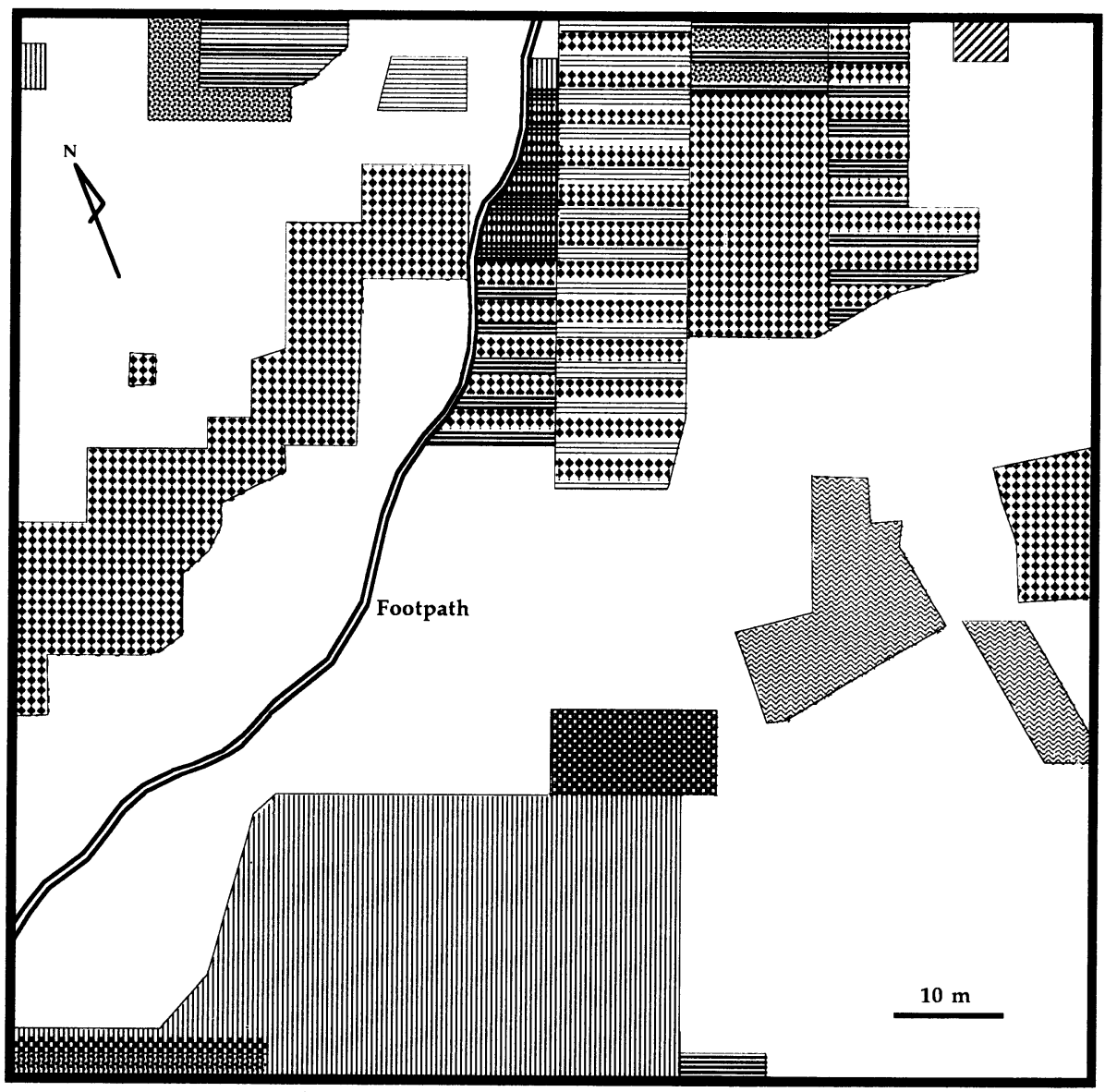

Fig. 3. Agricultural crops at Tree Garden Plot

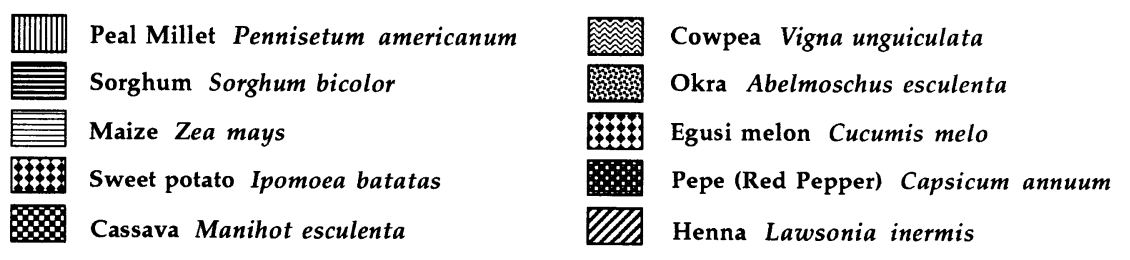

What can be explained concerning the land tenure system through brief interviews at village level is that all of the village territory is primarily ruled by two persons, etsu lati and etsu enunuchizhi, not owing to their positions but to decent. According to oral tradition of village people, their ancestors were living at Pategi, a town located at the junction of the Niger River and Kaduna River. To escape from slave hunting, the grandfather of etsu lati first settled at Gadza village and the grandfather of etsu enunuchizhi arrived four days later. Since that time the territory of the village has been divided into two parts and ruled by their descendants.

The secondary rulers are the people who are cultivating the land. Almost all of the households have their own allotments both in lowland and in upland. The right to occupy a certain part of land is inherited so far as it is under cultivation. Once the land is abandoned, it is returned to direct control of the primary ruler. The area of operational holdings of a household seems to correspond to the size of available working power of the household. For 


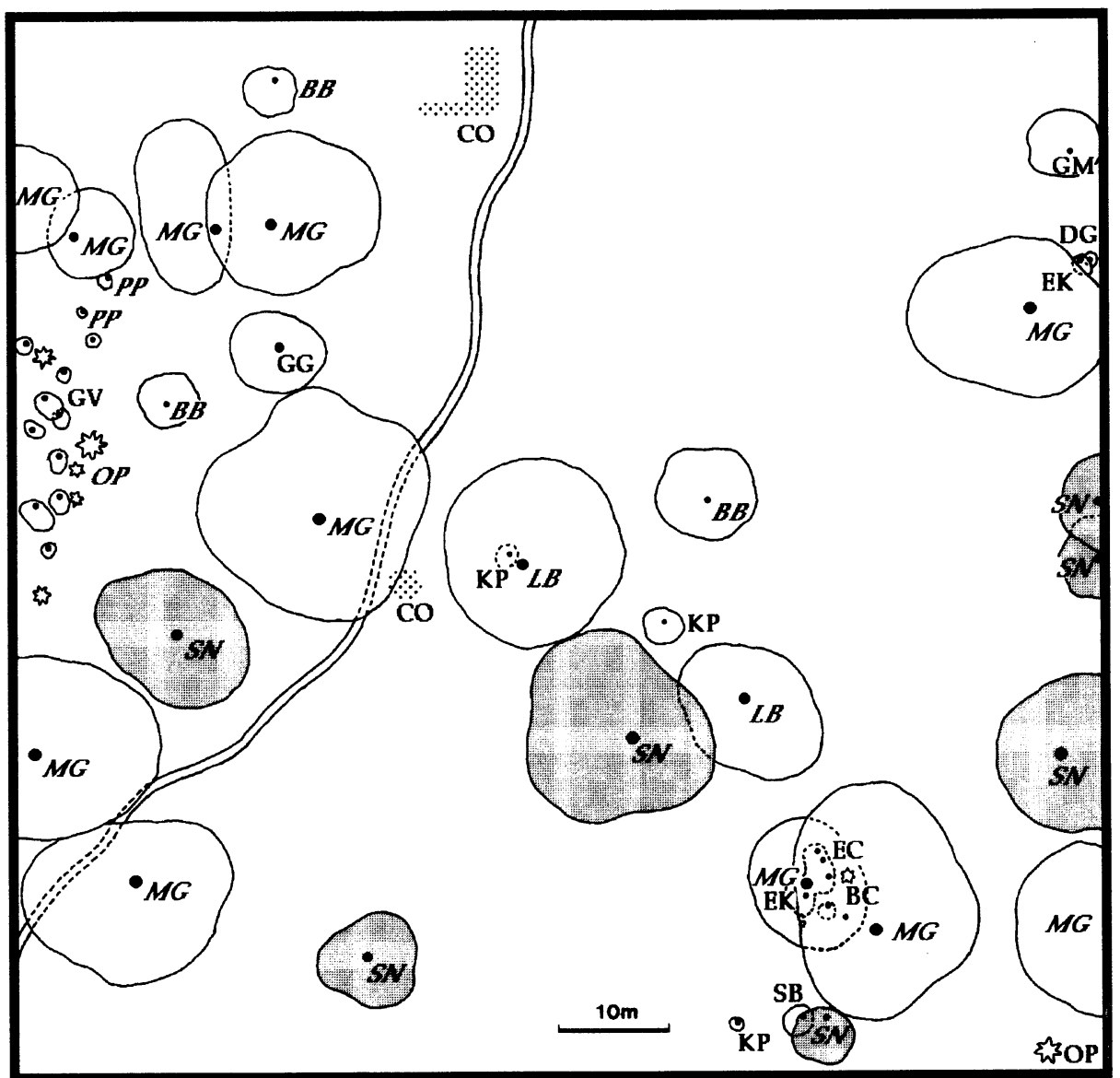

Fig. 4. Distribution of trees at Tree Garden Plot.

BB: Baobab Adansonia digitata, BC: Banchi Afzelia africana, CO: Castor oil plant Ricinus communis, DB: Dangodi, EC: Eyinchi, GG: Gbagun, GM: Gmelina Gmelina arborea, GV: Guava Psidium guajava, KP: Kutukpachi Bombax costatum, LB: Locust bean Parkia filicoidea, MG: Mango Mangifera indica, OP: Oil palm Elaeis guineensis, PP: Papaya Carica papaya, SB: Shambota, SN: Sheanut Butyrospermum paradoxum. Symbol in italic: Trees with ownership.

example, the eldest son who holds the largest family cultivates the largest area of land among the households of Emi A.

\section{Land use and crops at tree garden}

As it has already been mentioned, the land use patterns are obviously different among lowland, surroundings of the settlement, and upland in spite of flat topography of the village, where the altitude differs only approximately $50 \mathrm{~m}$ between the highest and lowest part. In lowland along the stream, paddy, and sugar cane in some parts, are cultivated during the rainy season under rudimentary irrigation system. Cassava is the main second crop. The primary source of income for the villagers is paddy, while the staple food crops in upland such as pearl millet and guinea corn (sorghum) are used for self consumption.

Land surrounding settlements is commonly used as tree garden. The arrangement of tree and agricultural crops at the sample plot of Gadza village is illustrated at Figure 3 and 4. 
Table 2. Number, DBH and basal area by species at Tree Garden Plot.

\begin{tabular}{|c|c|c|c|c|}
\hline \multirow[b]{2}{*}{ Species } & \multicolumn{3}{|c|}{ Number $\mathrm{DBH}$} & \multirow{2}{*}{$\begin{array}{c}\text { Basal area } \\
\text { Average } \\
\left(\mathrm{cm}^{2}\right)\end{array}$} \\
\hline & $\begin{array}{l}\text { of } \\
\text { trees }\end{array}$ & $\begin{array}{c}\text { Average } \\
(\mathrm{cm})\end{array}$ & $\begin{array}{l}\text { Total } \\
\left(\mathrm{cm}^{2}\right)\end{array}$ & \\
\hline Mango & 10 & 103.4 & $91,294.9$ & $9,129.5$ \\
\hline Sheanut & 6 & 45.4 & $11,331.9$ & $1,888.7$ \\
\hline Baobab & 3 & 109.6 & $29,767.5$ & $9,922.5$ \\
\hline Locust bean & 3 & 48.8 & $6,732.3$ & $2,244.1$ \\
\hline Kutupachi & 2 & 19.4 & 592.4 & 296.2 \\
\hline Gbagun & 1 & 71.0 & $3,957.3$ & $3,957.3$ \\
\hline Oil palm & 1 & 38.8 & $1,184.4$ & $1,184.4$ \\
\hline Banchi & 1 & 19.1 & 286.5 & 286.5 \\
\hline Gmelina & 1 & 15.9 & 198.9 & 198.9 \\
\hline Shambota & 1 & 15.9 & 198.9 & 198.9 \\
\hline Papaya & 1 & 10.2 & 81.5 & 81.5 \\
\hline Total & 30 & 66.4 & $145,626.5$ & $4,854.2$ \\
\hline
\end{tabular}

* Trees with $\mathrm{DBH}<10 \mathrm{~cm}$ are not included.

** The area of the plot is $100 \mathrm{~m} \times 100 \mathrm{~m}$ (1ha).

Though is not as highly developed in the sense of diversity and space density as that of humid areas, it can still be compared to home garden in Southeast Asia. Table 2 shows the total number, average diameter, and average basal area of trees and other perennial crops with DBH of more than $10 \mathrm{~cm}$ by species. Among these, planted species consist of baobab, gmelina (Gmelina arborea ROXB.), mango (Mangifera indica L.), oil palm (Elaeis guineensis JACQ.) and papaya (Carica papaya L.) account for $53.2 \%$ by number but $84.8 \%$ by basal area, which means these species are preferentially grown at this plot compared with other natural species, and even prior to agricultural crops.

These planted trees are owned by individuals, whose rights have been inherited from the persons who planted them. Gmelina is an exception, for which nobody claims the right, probably because it was introduced by the local government for revegetation but has no use for village people. Transaction of the ownership is observed on mango trees.

As to natural species, exclusive right to harvest locust bean and sheanut is claimed by the primary land ruler, while no rights are set on other species.

To the south of the settlement within the territory of Gadza village, there is another tree community mostly consisting of mango. This shows the site of another settlement which disappeared at the beginning of the 1950s on account of witchcraft, according to the belief of villagers. The right on these trees was inherited to the widow of the late emi tsuo of Emi A.

\section{Land use and crops in upland}

Upland fields are located along the path which runs through the village to avert the risk of pest damage, particularly that of monkeys. In the Nupe language, there are three terms to distinguish the states of fallow: enufu, gonta, and cikan. Enufu is grassland or newly abandoned land, and gonta is bush or land ready to be cleared. Cikan means far gonta, whose vegetation is almost the same as gonta but has less probability for agricultural land due to the 


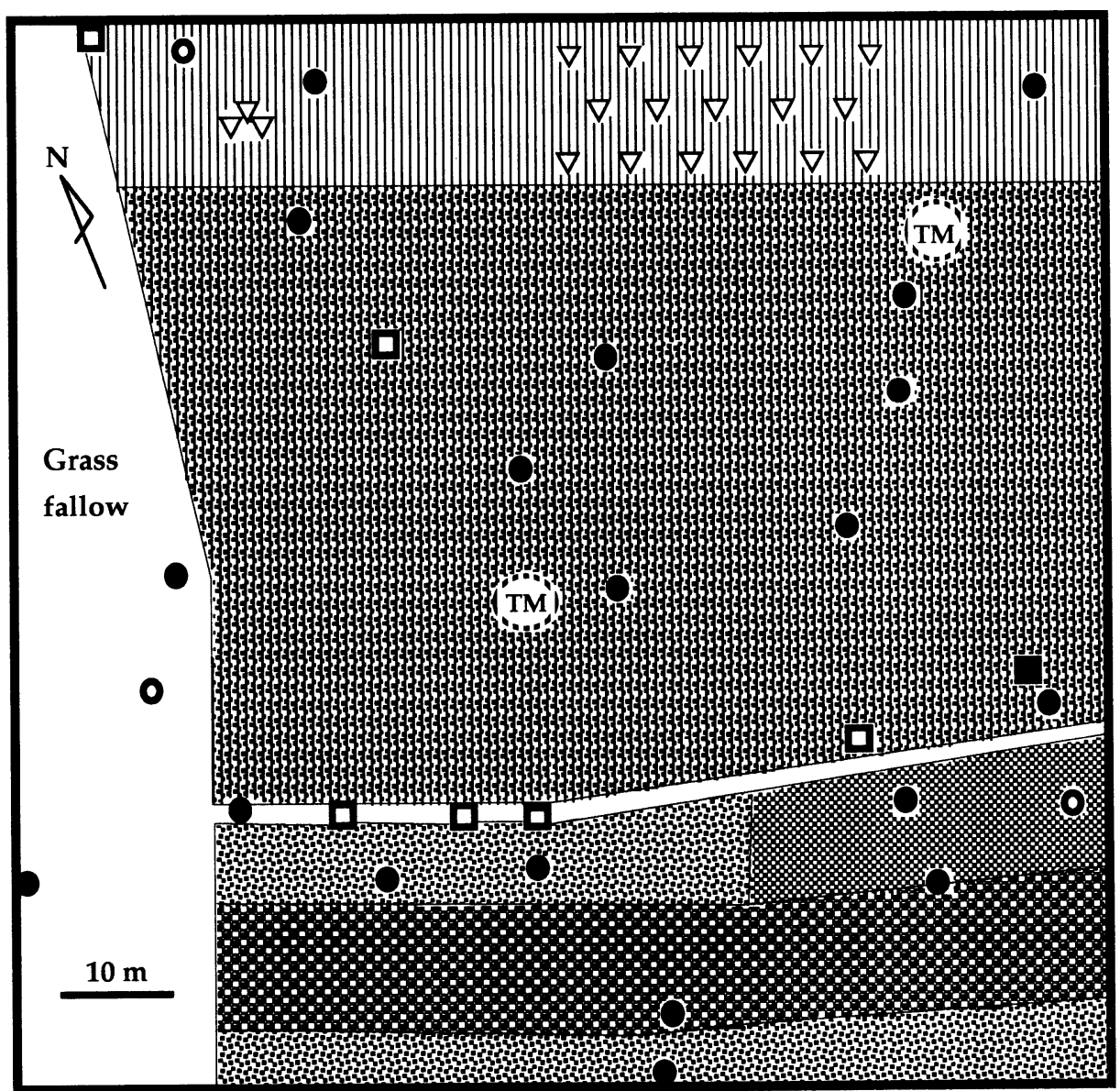

Fig. 5. Distribution of agricultural crops and trees at Upland Plot

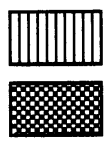

Millet

Pennisetum americanum

Bambara nut

Voandzeia subterranea

Sheeanut

- Locust bean

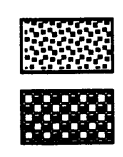

a Mango
Groundnut
Arachis hypogae

Red pepper Capsicum annum

Oil palm
55555555 Millet \& Ground nut

(TM) Termite mound

$\nabla$ Emagi Hibiscus subdariffa

distance. The rotation system in upland can be classified into long-cultivation, long-fallow type. A patch is normally cultivated for around seven to ten years without fertilizer but with cyclical introduction of leguminous crops, and then abandoned for fallow period of more than ten years.

Another remarkable way found at Gadza village is to maintain soil fertility under symbiotic relations with the nomadic Fulani people. It is not commonly practiced yet, but a villager has ever tried to make a contract with a Fulani group who used to engage in cattle grazing in upland of the village, and let them settle and provide herbage on his farmland during the dry season so as to utilize their barnyard manure. In exchange for it, the villager supplied the Fulani people with grain and cola nut (Cola nitida A. CHEV.) for courtesy. In this case, it is expected the cropping period can be extended for more than 10 years.

Using the estimated village area of around 250 ha by GPS measurement and population of 200 , the average land area comes to 1.25 ha per capita, or 10 ha per household assumed to 
Table 3. Number, DBH and basal area by species at Upland Plot.

\begin{tabular}{lcccc}
\hline Species & $\begin{array}{c}\text { Number } \\
\text { of } \\
\text { trees }\end{array}$ & $\begin{array}{c}\text { DBH } \\
\text { Average } \\
(\mathrm{cm})\end{array}$ & $\begin{array}{c}\text { Total } \\
\left(\mathrm{cm}^{2}\right)\end{array}$ & $\begin{array}{l}\text { Average } \\
\left(\mathrm{cm}^{2}\right)\end{array}$ \\
\hline Sheanut & 18 & 30.3 & 18,864 & 770 \\
Locust bean & 3 & 13.4 & 427 & 142 \\
Mango & 1 & 28.6 & 645 & 645 \\
Oil palm & 1 & 27.1 & 575 & 575 \\
\hline Total & 23 & 27.9 & 15,510 & 674 \\
\hline
\end{tabular}

* Trees with $\mathrm{DBH}<10 \mathrm{~cm}$ are not included.

**The area of the plot is $100 \mathrm{~m} \times 100 \mathrm{~m}$ (1ha).

consist of 8 persons. Taking the existence of cikan and lowland which can be cultivated continuously without fallow period into consideration, it can be said serious land shortage has not occurred yet at Gadza village under the current farming system and population size.

Figure 5 is to illustrate the distribution of trees and agricultural crops, and Table 3 shows the number, average diameter, and basal area of trees by species. It is evident from these that sheanut and locust bean are selectively reserved at the time of land clearing. The nature of fire tolerance may also promote the survival rate of these two species after burning. Compared with the size at the plot of tree garden, however, the average basal area of sheanut at this plot accounts for $40.8 \%$ in spite of larger number of trees per ha, probably due to the stress of burning and trimming for shade control or other small purposes on farmland. The priority is given to agricultural crops and apart from sheanut and locust bean, no other natural tree species with less usefulness appear at this plot.

Among tree species in upland, ownership is only found on saplings of mango, baobab and oil palm recently planted along borders of fields by children, while there are no exclusive rights on natural trees including sheanut in contrast to the tree garden.

\section{Sheanut production and utilization by village people}

Apart from nuts, sheanut trees produce protein source for village people by rearing caterpillars on leaves and mole crickets under ground around stems (both species could not be identified). Sheanut caterpillars outbreak at the beginning of the rainy season and eat up all the leaves. Nevertheless, trees do not wither and it is more of a welcome phenomenon than damage for villagers. Gathering of caterpillars is mainly done by women and children, and the surplus is smoked for preservation which lasts for several months. Mole crickets are occasionally caught by men and boys during farm work. In addition, the resin of trees is used as a substitute of chewing gum by children.

Sheanuts are harvested from May to July only by women and girls, as it is not necessary to climb trees but just to collect fallen fruit around trees. Sweet pulp enveloping kernels is edible and can be easily removed after drying. Among members of $E m i$ A, 7 wives and 2 girls engaged in harvesting at the season in 1992. They engaged in collecting individually within 
the village territory and most of them sold the harvest to a middleman from Bida. One of them sold the products to the old widow of Emi A who had capital to buy and hold them for better prices. The average yield of dried kernels per capita was $73.5 \mathrm{~kg}$, which was sold for 108.1 Naira. The incomes were used for their own purpose, mostly for dressing. Since there are few resources at women's disposal inside the village, sheanut harvesting is one of important production activities for women despite limited income from it.

In the whole village, there was nobody that kept collected nuts for self consumption. They prefer to use palm oil or groundnut oil for cooking, and even in case of using sheanut butter as frying oil, they buy it at markets because of the laborious work to extract fat from kernels. At $E m i \mathrm{~A}$, only a girl used shea butter to fry bambara nut cakes to earn pocket money.

Sheanuts collected by middlemen from villages are gathered at Bida, some are processed at an oil mill newly established at Bida for domestic market, and the others are exported as raw material. There may also be small home industry of fat expression, but could not be confirmed through this study.

\section{CONCLUSION}

Though there are no statistical data on sheanut production, it can be said domestic market of shea butter for cooking has already been replaced by other vegetable oil, as shown in the case of Gadza village. Besides, shea butter is used for lamplight, medication balm, and cosmetics, and as a substitute of cacao butter (Forest Research Institute of Nigeria, Ibadan, interview). The former two are also traditional use, but it is questionable whether there are still many villages utilizing shea butter for light. In the latter two cases, the market depends on foreign demand, particularly in Europe and Japan. Considered from Table 4, recent export of sheanut is less than the best time, but not far different from the trend of the period from the 1900s to the 1930s. On the other hand, Japan itself annually imports around 10,000 tons of sheanut from West Africa as shown at Table 5.

Accordingly, it can be said declining trend in production is basically derived by falling domestic demand, but not due to exploitation of trees by local people themselves. Protection of sheanut trees has already been internalized to customary activities as trees arranged on farmland. They never fell sheanut trees, though they may cut branches for shade control or other purposes. Conversely speaking, it is necessary for farmers to arrange trees, not always sheanut, on farmland so as to take rest under the shade, especially for children watching matured crops against mammal damage. Granted that even if felling of sheanut trees by local people occurred in some places, it did not result from lack of their knowledge on forest protection, but from that the trees have lost the usefulness in their daily life or made no contributions to their income any more. In all cases, the most extensive felling activities should be found at large-scale land clearing for agricultural farms which covered 170,553 ha of the state, including land enclosed for future clearing, during the period from 1984 to 1988 (Niger State Committee for Desertification Problems, 1988).

In discussing the way how to protect the remaining tropical forests, it is generally pointed 
Table 4. Export of sheanut from Nigeria.

\begin{tabular}{|c|c|c|c|}
\hline & Country & Export & heanut \\
\hline Year & $\begin{array}{c}\text { of } \\
\text { destination } \\
\end{array}$ & $\begin{array}{l}\text { Quantity } \\
\text { (ton) }\end{array}$ & $\begin{array}{l}\text { Value } \\
\text { (Naira) }\end{array}$ \\
\hline 1979 & Total & 9,263 & $2,844,406$ \\
\hline & Denmark & 4,118 & $1,228,928$ \\
\hline & United Kingdom & 3,524 & $1,066,401$ \\
\hline & Japan & 1,621 & 549,077 \\
\hline 1983 & Total & 4,653 & $1,024,722$ \\
\hline & Denmark & 1,300 & 281,200 \\
\hline & Japan & 3,353 & 743,522 \\
\hline 1986 & Total & 8,506 & $4,011,088$ \\
\hline & Denmark & 4,556 & $1,516,968$ \\
\hline & United Kingdom & 450 & 123,284 \\
\hline & British Sol Isl & 1,000 & 260,000 \\
\hline & Unspecified & 2,500 & $2,110,836$ \\
\hline 1987 & Total & 8,609 & $6,872,626$ \\
\hline & Benin & 1,000 & 204,000 \\
\hline & Denmark & 80 & 84,000 \\
\hline & United Kingdom & 7,500 & $6,522,604$ \\
\hline & India & 29 & 62,022 \\
\hline $1988^{*}$ & Total & 625 & 519,700 \\
\hline & United Kingdom & 100 & 90,495 \\
\hline & Japan & 525 & 429,205 \\
\hline
\end{tabular}

* Data from Jan. to Jun. 1988

Source: Federal Office of Statistics. 1979, 1983, 1986, 1987, 1988

Table 5. Import of sheanut in Japan.

\begin{tabular}{lrrrrrr}
\hline \multirow{2}{*}{ Country } & \multicolumn{1}{c}{1986} & \multicolumn{2}{c}{1987} & \multicolumn{2}{c}{1988} \\
& Quantity & Value & Quantity & Value & Quantity & Value \\
& Ton & $¥ 1,000$ & Ton & $¥ 1,000$ & Ton & $¥ 1,000$ \\
\hline Ivory coast & 17 & 2,633 & 4,327 & 302,117 & 3,528 & 163,805 \\
Ghana & 3,990 & 532,505 & - & - & 1,500 & 71,800 \\
Togo & 2,729 & 312,612 & 2,995 & 211,894 & 4,285 & 177,589 \\
Mali & 253 & 24,231 & 516 & 33,420 & - & - \\
Burkina Faso & 3,269 & 300,858 & 3,690 & 245,361 & 200 & 7,181 \\
Nigeria & - & - & - & - & 521 & 19,259 \\
\hline Total & 10,258 & $1,172,839$ & 11,528 & 792,792 & 10,034 & 439,634 \\
\hline
\end{tabular}

Source: 大蔵省編『日本貿易年表』1986，1987，1988年

out that local people hold the key to solve the problem. It is a matter of course, especially in the region where forest land and resources are controlled under customary usufruct. In Nigeria, only $9.8 \%$ of the total land is reserved as forest land and national parks, the former owned and managed by the state governments, while the latter by the federal government. Diminishing forest resources have caused timber shortage in concurrence with desertification problem. Therefore, not only to take a proper step to expand the area of forest reserve, which 
seems very difficult to be realized under present situations, but to encourage tree planting activities of local people on their land become an urgent necessity. Sheanut ranges so widely not only in forest land but more in farmland that to cultivate and stabilize the international market of sheanut or butter seems the nearest way to protect the trees. In addition, so far as the traditional tree protection system remains, it is within the bounds of possibility to introduce other tree species on farmland or fallow land.

ACKNOWLEDGEMENTS This research project was carried out from August to September 1992 under financial support of Japan Society for Promotion of Sciences, conducted by WAKATSUKI Toshiyuki, Shimane University, and Ayodele FAGBAMI, University of Ibadan. We would like to acknowledge the agencies and persons concerned, particularly Forest Research Institute of Nigeria and people of Gadza village.

\section{REFERENCE}

Allen, W. \& T. R. H. Thomson. 1968. A Narrative of the Expedition sent by Her Majesty's Government to the River Niger in 1841. 2 Vols. Frank Cass, London.

Barbour, K. M., et al. 1982. Nigeria in Maps. Hodder \& Stoughton, London.

Buchanan, K. M. \& J. C. Pugh. 1955. Land and People in Nigeria: the Human Geography of Nigeria and its Environmental Background. Univ. of London Press, London.

Dike, K. O. 1956. Trade and Politics in the Niger Delta 1830-1885: an Introduction to the Economic and Political History of Nigeria. Clarendon, Oxford.

Federal Ministry of Agriculture. 1982. An Outline of Nigerian Agricultural Policy. Lagos.

Federal Ministry of Agriculture, Water Resources and Rural Development. 1988. Agricultural policy for Nigeria: Strategies for Implementation. Lagos.

Federal Office of Statistics. 1979. 1983. 1986. 1987. 1988. Nigeria Trade Summary. Lagos.

Imperial Institute. 1920. Reports on Oil-seeds: Indian Trade Enquiry. Imperial Institute, London.

Momodu, A. B. 1987. The prospects for development of shea butter industry in Nigeria. In: A. B. Oguntala (ed.), The Role of Forestry in a Depressed Economy: Proceedings of the 17th Annual Conference of the Forestry Association of Nigeria 6-10 December 1987 Ikeja, Lagos State, Nigeria. Forestry Association of Nigeria, Lagos.

Niger State Committee on Desertification Problems. 1988. Report of the Niger State Committee on Desertification Problems. unpublished, Minna.

Roche, L. 1989. Forestry and famine: arguments against growth without development. The Ecologist 19 (1): 16-21.

Stebbing, E. P. 1937. The Forests of West Africa and the Sahara: a Study on Modern Conditions. W. \& R. Chambers, London.

Received Jan. 6, 1993

Accepted April 10, 1993 
増田 美砂, Suleiman KUDU 農地に打ける樹木の配置：ナイジェリア共和国ナイジャ 州におけるシアナットの分布と生産

シアナットButyrospermum paradoxum はインドのモウラナットおよびボルネオ島のテンカワンと ならぶ熱帯林の産する重要な油脂原料である。西アフリカのサヴァンナ帯に天然に分布し, 住民 はその種子に含まれる脂肪を食用および灯火に利用してきた。20世紀に入るとナイジェリア北部 の重要な産物として, 加工された油脂は地域で消費され，種子はヨーロッパ市場に輸出された。 しかし第 2 次大戦後その地位は急速に失墜し, 経済関係のみならず林業関係の文献からもシアナ ットは姿を消すにいたった。ところがその要因に関しては, ナイジェリア全域で進行しつつあり， 今日深刻な社会問題となっている森林破壊に関連づけた推測がなされているにすぎない。

本研究では, 車中からの観察により, 樹木そのものは南部のイバダン近辺から北部に国境を接 するニジェールに至るまで広汎に見られることを確認するとともに，かつてザリアとならぶ集荷 の中心地であったナイジャ州ビダ近郊の農村を事例にとり, 測量および住民に対するヒアリング を行った。その結果, 植林は行われていないものの畑地にはシアナットおよびローカスト・ビー ンの 2 種が選択的に残されており, 収穫は女性のみによってなされ，そこからえられる収入は僅 かな額にすぎないが，可処分所得を制限されている村の女性にとっては収穫および村に買い付け に来る仲買人への販売は重要な経済活動のひとつであることがわかった。その反面, 村には収穫 した種子を加工するものはなく，ヒアリングの対象に選んだ34名からなる一族の中では，1名だ けが市場で購入したシア・バターを利用していた。また集落に隣接する樹木作物を優先的に配し た区画との比較によると, シアナットの単位面積当たりの本数は畑地の方が多いが, 平均断面積 は $40 \%$ にすぎないことから，烟地に配された樹木には火入れや枝葉の刚り取りによるストレスが かかっているものと推察される。

こうしたことから，少なくともナイジャ州では，生産減少の要因は農民による開墾に伴う樹木 の伐採ではなく，特に国内需要の低下および大規模農園開発に求められるべきであることがわか る。また住民は彼ら自身にとって有用な樹木は慣習的に残しているが，今後さらなる市場の縮小 と燃料材の不足が生じれば，シアナットが伐採の対象となる可能性も危惧される。国公有林地面 積が国土のわずか $9.8 \%$ にすぎないナイジェリアにおいては, シアナットのように住民の生活と 深い係わりをもった樹木を，その産物の市場拡大や価格安定化によって間接的に保護するととも に，私有地における樹木密度の拡大を促す諸施策の導入が望まれる。 